Original Paper http://ajol.info/index.php/ijbcs http://indexmedicus.afro.who.int

\title{
Insecticide resistance in field populations of the tomato fruitworm, Helicoverpa armigera, from Senegal
}

\author{
Serigne Omar SENE*, Etienne TENDENG, Mamadou DIATTE, Serigne SYLLA, \\ Babacar LABOU, Amadou Woory DIALLO and Karamoko DIARRA
}

Université Cheikh Anta Diop (UCAD), Laboratoire Production et Protection Intégrées en Agroécosystèmes

Horticoles - L2PIA, Faculté des Sciences et Techniques, Dakar, Sénégal.

${ }^{*}$ Corresponding author; E-mail: pape.o.sene44@gmail.com; Tel : +221 774410498

\begin{abstract}
Monitoring of the evolution of insecticide resistance in the field is crucial to prevent pest control issues. The present study was conducted to assess insecticide resistance status of the fruitworm, Helicoverpa armigera (Hübner) (Lepidoptera, Noctuidae), the most destructive pest of field-grown tomato in Senegal. A sample of 1115 field populations were monitored for their susceptibility to abamectin, deltamethrin, and profenofos, using a standard leaf-dip bioassay method. Resistance ratios ranged from 1 - to 30 -fold to abamectin (4/15 populations with $R R>10)$, 7- to 112-fold to deltamethrin (11/12 populations with $R R>10)$, and 1- to 29-fold to profenofos (3/11 populations with $R R>10)$. This indicates that resistance evolution to deltamethrin was widespread among field populations of $H$. armigera. However, an increasing trend of resistance to deltamethrin was observed from the South to the North of Niayes. Susceptibility to abamectin and profenofos was generally high but showed that resistance might be evolving within some populations. In addition, signs of cross-resistance to abamectin were detected, suggesting possible metabolic resistance mechanisms already selected in pyrethroid-resistant populations. The recorded high levels of pyrethroids resistance are a concern for the control of $H$. armigera in Senegal as the country is being currently embarking into economic expansion of tomato cropping systems.
\end{abstract}

(c) 2020 International Formulae Group. All rights reserved.

Keywords: Insecticide resistance, pyrethroids, avermectins, OPs, Helicoverpa armigera, West Africa.

\section{INTRODUCTION}

In Senegal, vegetable production experiences an annual variation of $12 \%$. This increase in production is linked to the increase in the area planted. The tomato is the most cultivated crop behind the onion and is one of the most consumed vegetables. Its production experiences an annual variation of around 9\% and represents around $11.9 \%$ of the total vegetable production estimated at $1,212,911$ tons for the 2017/2018 campaign (ANSD, 2019). In the Niayes, tomato crops are grown for fresh market throughout the year with a peak during the dry season, while in the "Walo", the tomato is grown once a year mostly for industrial processing.

The tomato fruitworm, Helicoverpa armigera (Hübner) (Lepidoptera, Noctuidae), is a serious pest causing substantial damages to a wide range of field and vegetable crops 
worldwide, including cotton, maize, sorghum, and tomato (Cunningham and Zalucki., 2014; CABI, 2016). It is a polyphagous pest (Tendeng et al., 2017; Diatte et al., 2018) which presents a broad spectrum of distribution. In West Africa, H. armigera is the most damaging pest of field-grown tomato crops (Umeh et al., 2002; Huat, 2006; Mailafiya et al., 2014). It has been reported in almost all West African country. Its biological and ecological traits such as high reproduction rate, polyphagy, high mobility, migratory flights, facultative diapause, and propensity to develop resistance to insecticides, make it difficult to control (Torres-Vila et al., 2003; Martin et al., 2005; Achaleke et al., 2009). In Senegal, extensive monitoring of a set of 98 tomato fields in the Niayes area from October 2012 to May 2014 indicated that $H$. armigera was the most destructive pest, with an occurrence of $92 \%$ in sampled fields (90/98) (Diatte et al., 2018).

Economic damage caused by $H$. armigera is very significant worldwide (Sharma, 2005). Losses caused in Africa are estimated at more than US $\$ 5$ billion annually despite application of pesticides (Sharma, 2005). Monetary losses are the result of monitoring and control costs, using insecticides, and the direct reduction of yield. Damage to high-value crops including tomatoes, has a high socio-economic cost. In Senegal, yield losses on tomatoes can be higher than $28 \%$ (Diatte et al., 2016). A positive relation between the number of insecticide applications and the incidence of $H$. armigera indicated that insecticide strategies were not effective (Diatte et al., 2018). Such control failure is likely due to the evolution of resistance in $H$. armigera field populations.

Resistance of $H$. armigera to a wide range of insecticides has been reported worldwide (Mironidis et al., 2013). Pyrethroid and organophosphate insecticides have been widely used by both cotton and tomato growers on account of their efficacy in controlling a wide range of pests at low doses and at extremely low cost (Badiane et al., 2015). As a result, resistance to pyrethroids occurred during the mid-1990s in $H$. armigera populations from West Africa (Martin et al., 2000; Djihinto et al., 2012). Resistance led to the wide adoption of a new spraying program based on the temporary exclusion of pyrethroids (Martin et al., 2005). Field-evolved resistance to almost all the insecticides available for their control has been documented in other regions, including profenofos (Alvi et al., 2012; Qayyum et al., 2015) and abamectin (Alvi et al., 2012) in Asia. To date, no case of resistance to OPs or avermectins has been reported for $H$. armigera in Africa (Achaleke et al., 2009). The possible loss of effectiveness of insecticide molecules due to resistance is a major issue for both farmers and the industry. In addition, subsequent pest outbreaks might lead to generalized use of even more toxic insecticides, with unintended effects on human health, biodiversity within agroecosystems, particularly non-target species such as natural enemies of the pest species, and risk on safety of fresh tomatoes due to insecticide residues. In Senegal, H. armigera resistance status has been poorly documented and conventional insecticides continue to be used in vegetable growing areas, with sometimes low efficacy. According to Diarra (personal communication), H. armigera is insensitive to pyrethroids and organophosphorus in some areas of the Niayes and the Senegal River Valley.

The objective of the present study was to assess the susceptibility to commonly used insecticides (abamectin/avermectin, deltamethrin/pyrethroid, and profenofos/OP) of $\mathrm{H}$. armigera populations in the main vegetable-growing area in Senegal (Niayes). Such monitoring should provide crucial information on the scope, variability and magnitude of insecticide resistance in tomatogrowing areas in Senegal, for the sound design of adaptive areawide insecticide resistance management programs and effective pest control strategies. 


\section{MATERIALS AND METHODS \\ Insects sampling}

Eleven populations of $H$. armigera larvae were collected from tomato fields over two dry seasons, from February 2014 to March 2015 , in the main vegetable-producing area in Senegal, "Niayes" (Figure. 1, Table 1). The environment of Niayes is characterized by dunes and often flooded depressions, and the alternation of a short rainy season (JulySeptember) and a long dry season (OctoberJune). It is subdivided into three different ecogeographic sub-areas because of the existence of a climatic gradient and the variation of the soils encountered between the South and the North. The southern zone, slightly arid, is characterized by a Sudano-Sahelian climate and low hygrometric conditions (temperature, relative humidity), regulated by the sea. The ferruginous tropical soils, little leached are predominant. The central zone, moderately arid, is marked by a Sudano-Sahelian climate. It is dominated by hydromorphic soils of depressions very favorable to the development of market gardening. The highly arid northern zone is characterized by a Sahelian climate and high temperatures. Iso-humic red-brown soils are more important (Ndiaye et al., 2012).

Two additional populations were collected from tomato (Mbour) and cotton (Koussanar) fields out of the two abovementioned tomato-growing areas. A

minimum of 100 larvae (second to fourth instar) were randomly collected by walking through at least two plots of a particular crop in a zig-zag manner to get a mixed population from sampling locations.

Field-collected larvae were individually incubated in the laboratory at $27 \pm 2{ }^{\circ} \mathrm{C}, 60 \pm$ $10 \% \mathrm{RH}$, and a photoperiod of 14:10 (L: D) h, in 6-well culture plates (Fisher Scientific, France) containing cubes of artificial diet (Southland Products, USA). Resulting moths (from 25 to 141 per colony) had free access to $10 \%$ honey-water solution. Eggs laid on cheesecloth were collected daily. The laboratory susceptible strain of $H$. armigera was obtained from field collected populations and reared in the laboratory for two years without any exposure to insecticides.

\section{Insecticides}

Insecticide solutions were prepared from technical-grade materials. Cypermethrin (97\%) and profenofos (90\%) were provided by SPIA (Dakar, Senegal), and abamectin (90\%) by Senchim (Dakar, Senegal). Pyrethroids affect the sodium-potassium channel of target insect, whereas OPs act as inhibitors of acetylcholinesterase in the target insect (Ahmad et al., 2007). Abamectin (avermectin B1) is the major fermentation component of avermectins derived from a soil actinomycete microorganism (Streptomyces avermitilis) and act agonistically on GABA and glutamategated chloride channels. For each insecticide, a stock solution was prepared in a $100-\mathrm{ml}$ glass vial by dissolving the active ingredient in $3 \mathrm{ml}$ of ethanol $(90 \%)$ and distilled water. Five to seven serially diluted solution of each active ingredient and one control solution with only 3 $\mathrm{ml}$ of ethanol $(90 \%)$ and distilled water were prepared. Two droplets of surfactant (Triton X100) were added to each solution.

\section{Leaf-dip bioassays}

Bioassays were conducted using a standard leaf dipping bioassay method adapted from The Insecticide Resistance Action Committee (IRAC) method No. 7 (IRAC, 2014). Five-centimeter cotton (Gossypium hirsutum) leaf discs were dipped into the test solutions for $10 \mathrm{~s}$. Discs were then dried at room temperature for 30-60 min and placed in a Petri dish with adaxial side up. Five newlymoulted second-instar larvae from $F 1$ laboratory cultures were released on to each leaf disc. Petri dishes were then wrapped with Parafilm to prevent leaf desiccation. Two to six replicates were used for each test and control solution. Treated larvae were kept at a constant temperature of $27 \pm 2{ }^{\circ} \mathrm{C}, 60 \pm 10 \% \mathrm{RH}$, and a photoperiod of 14:10 (L: D) h. Petri dishes were covered with a black cloth to avoid cannibalism (Ahmad, 2004). Mortality was observed $48 \mathrm{~h}$ later. Larvae were considered 
dead when no coordinated response was obtained from touch stimulation with a blunt needle. A test was discarded when mortality in the control exceeded $20 \%$.

\section{Data analyses}

Bioassay data were analyzed with XLSTAT Version 2018.1 (Addinsoft) using the 'Dose effect' module based on Finney's log-probit method (Finney, 1971). The $\mathrm{LC}_{50}$ (the concentration that kills $50 \%$ of the test population, expressed in mg. $1^{-1}$ of insecticide solution) and their respective $95 \%$ fiducial limits were calculated. Significant differences in the susceptibility of populations were established by non-overlapping 95\% fiducial limits. Resistance ratios (RR) were calculated as $\mathrm{LC}_{50}$ of field populations divided by $\mathrm{LC}_{50}$ of the susceptible strain (LAB). Resistance ratios $>10$ were considered as demonstrating fieldevolved resistance (Che et al., 2013). Nonparametric Kruskal-Wallis tests were performed to compare insecticide resistance ratios among the three main areas: North, Centre and South of Niayes. Pairwise Pearsoncorrelation tests of $\log \mathrm{LC}_{50}$ values of insecticides were done to assess crossresistance of $H$. armigera populations to tested insecticides.

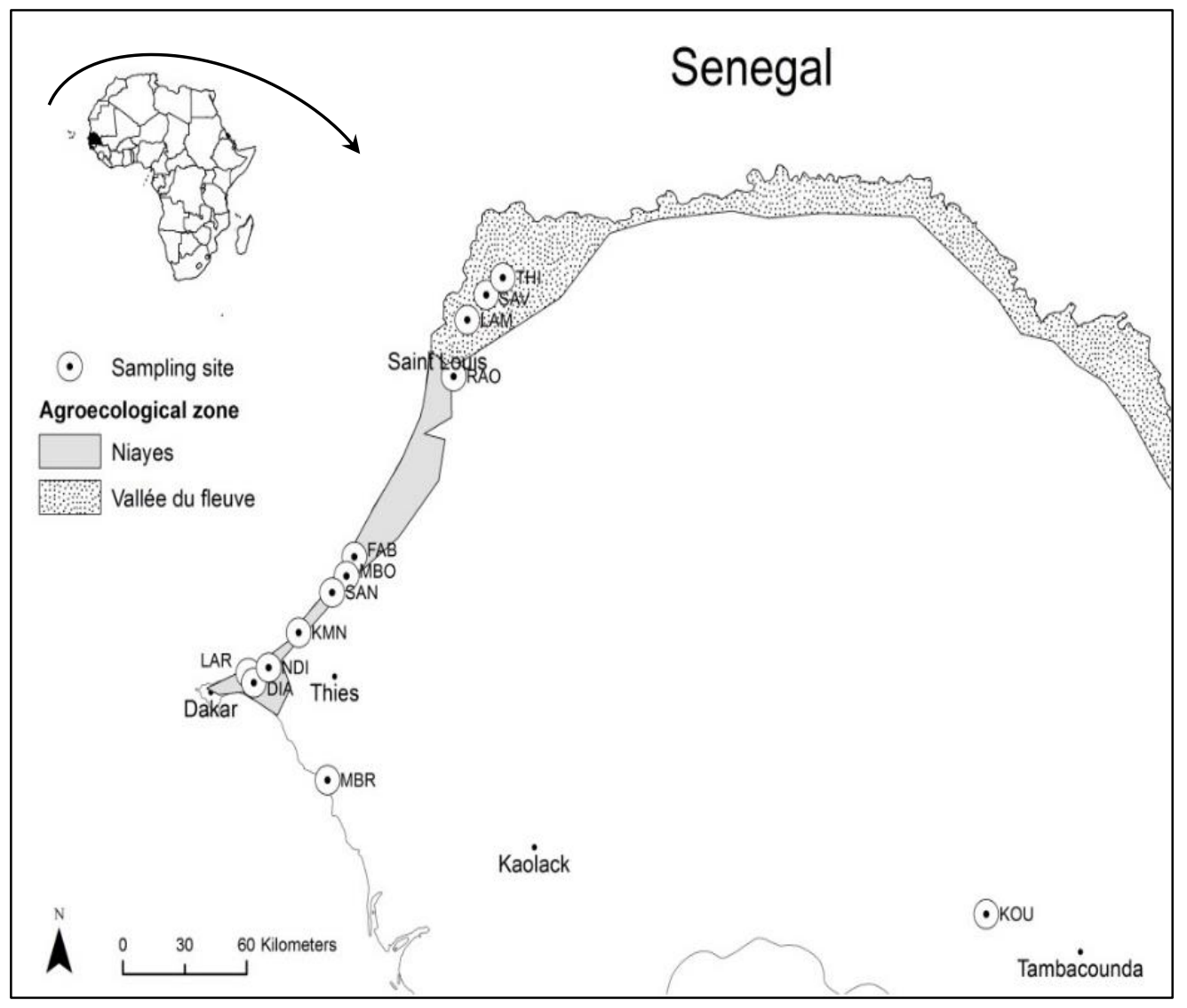

Figure 1: Field sampling of Helicoverpa armigera populations from Senegal. LAM (Lampsar), SAV (Savoigne), THI (Thilène), RAO (Rao), FAB (Fass Boye), MBO (Mboro), SAN (Santhié Ndong), DIA (Ndiakhirate), KMN (Keur Mbir Ndao), LAR (Lac rose), NDI (Ndiéguène), KOU (Koussanar), and MBR (Mbour). 
Table 1: Location, collection date, and host plant of field-collected populations of Helicoverpa armigera tested in bioassays.

\begin{tabular}{llllll}
\hline Area & Location & $\begin{array}{l}\text { Map } \\
\text { code }\end{array}$ & Collection date & $\begin{array}{l}\text { Host } \\
\text { plant }\end{array}$ & Nb of pupae \\
\hline North & Lampsar & LAM & Feb. 2014 & Tomato & 107 \\
Niayes & Savoigne & SAV & Mar. 2015 & Tomato & 55 \\
& Thilène & THI & Mar. 2015 & Tomato & 73 \\
& Rao & RAO & Febr. 2015 & Tomato & 71 \\
Centre & Fass Boye & FAB & Feb. 2014 & Tomato & 124 \\
Niayes & Fass Boye & FAB & Feb. 2015 & Tomato & 141 \\
& Mboro & MBO & Feb. 2014 & Tomato & 118 \\
& Mboro & MBO & Feb. 2015 & Tomato & 113 \\
& Santhié Ndong & SAN & Jan. 2015 & Tomato & 105 \\
South & Ndiakhirate & DIA & Jan. 2015 & Tomato & 121 \\
Niayes & Keur Mbir Ndao & KMN & Dec. 2014 & Tomato & 112 \\
& Lac rose & LAR & Jan. 2015 & Tomato & 117 \\
& Ndiéguène & NDI & Feb. 2014 & Tomato & 89 \\
\hline \multirow{2}{*}{ Others } & Koussanar & KOU & Oct. 2016 & Cotton & 121 \\
& Mbour & MBR & Mar. 2015 & Tomato & 78 \\
\hline
\end{tabular}

Map code: see Fig. 1. Nb of pupae: number of pupae obtained from field-collected H. armigera larvae.

LAM (Lampsar), SAV (Savoigne), THI (Thilène), RAO (Rao), FAB (Fass Boye), MBO (Mboro), SAN (Santhié Ndong), DIA (Ndiakhirate), KMN (Keur Mbir Ndao), LAR (Lac rose), NDI (Ndiéguène), KOU (Koussanar), and MBR (Mbour).

\section{RESULTS}

The status of insecticide resistance to commonly used insecticides (abamectin, deltamethrin, and profenofos) was assessed on 11-15 field-collected populations of $H$. armigera (Figure. 2, Table 1). Resistance ratios ranged from 1- to 30 -fold to abamectin (4/15 populations with $\mathrm{RR}>10$ ), 7 - to 112 -fold to deltamethrin (11/12 populations with $R R>10)$, and 1- to 29-fold to profenofos (3/11 populations with $R R>10$ ) (Table 2). This indicates that resistance evolution to deltamethrin was widespread among field populations of $H$. armigera. For abamectin and profenofos, susceptibility was generally high but RR suggested that resistance might be evolving in some populations. No significant difference of RR was observed among sampling areas for abamectin $(\mathrm{K}=1.70, \mathrm{df}=2$, $\mathrm{P}=0.427)$ and profenofos $(\mathrm{K}=2.49, \mathrm{df}=2, \mathrm{P}$ $=0.288$ ). However, an increasing trend of resistance to deltamethrin was observed from the South to the North of Niayes $(K=6.16$, df $=2, \mathrm{P}=0.042$ ). The population of $H$. armigera collected from tomato fields at Mbour (MBR) showed low susceptibility to both abamectin $(\mathrm{RR}=30)$ and deltamethrin $(\mathrm{RR}=48)$. The population sampled from cotton (KOU) showed high susceptibility to abamectin and profenofos $(\mathrm{RR} \approx 1)$, and moderate level of resistance to deltamethrin $(R R=13)$. Pairwise correlation of $\log \mathrm{LC}_{50}$ values of insecticides showed a significant correlation between abamectin and deltamethrin $(\mathrm{P}=0.025)$, indicating cross-resistance. 

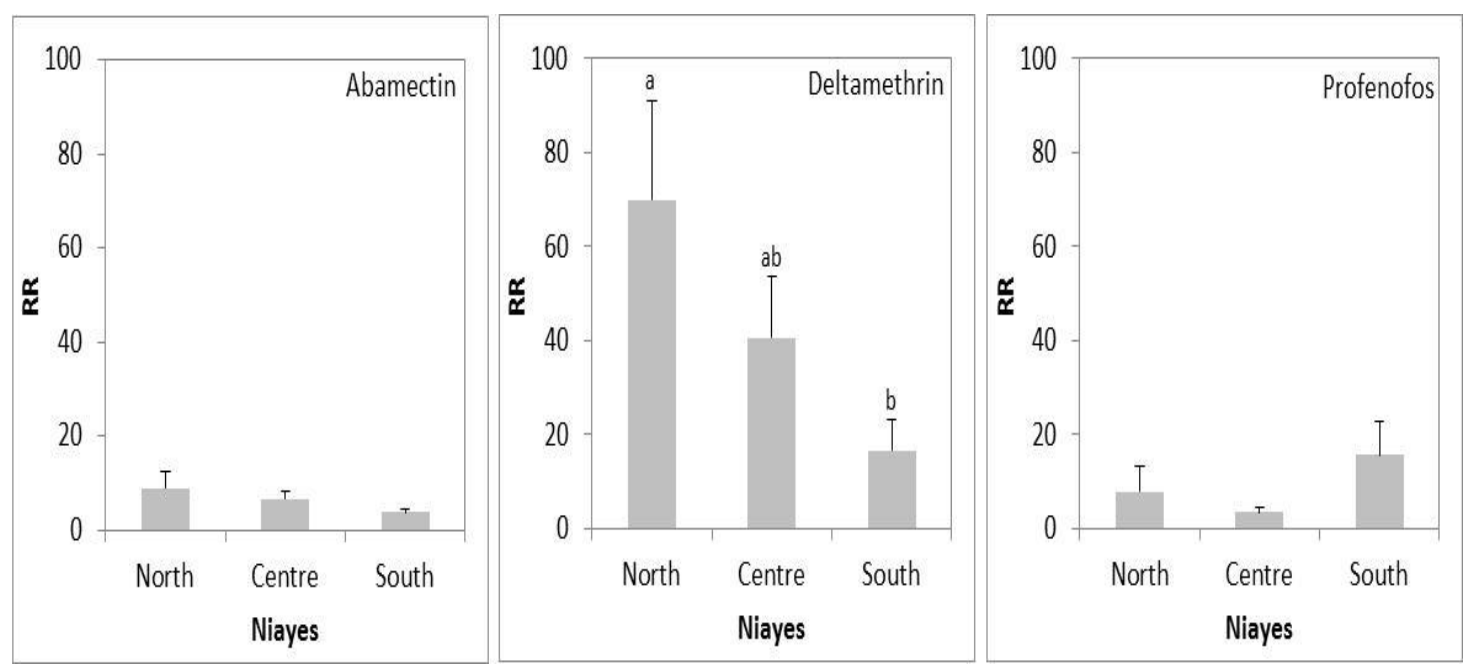

Figure 2: Resistance patterns of Helicoverpa populations to abamectin, deltamethrin and profenofos (2014-15) along the Niayes area in Senegal.

Table 2: Susceptibility of field populations of Helicoverpa armigera to three commonly used insecticides (abamectin, deltamethrin, and profenofos) in tomato-growing areas in Senegal.

\begin{tabular}{lllllll}
\hline Insecticide & Population & Slope $\pm \mathbf{S E}$ & $\begin{array}{l}\mathbf{L C}_{\mathbf{5 0}} \\
\left(\mathbf{m g . \mathbf { l } ^ { - 1 }}\right)\end{array}$ & $\mathbf{9 5 \%} \mathbf{F L}$ & $\mathbf{R R}$ & $\mathbf{N}$ \\
\hline Abamectin & LAB & $3.41 \pm 1.69$ & 0.46 & $0.00-0.79$ & 1.0 & 210 \\
& LAM & $3.70 \pm 1.73$ & 3.48 & $0.07-5.33$ & 7.6 & 70 \\
& SAV & $1.19 \pm 0.40$ & 8.36 & $4.31-39.2$ & 18.2 & 70 \\
& THI & $1.16 \pm 0.40$ & 4.02 & $1.56-9.29$ & 8.7 & 70 \\
& RAO & $2.49 \pm 0.58$ & 0.73 & $0.29-1.09$ & 1.6 & 210 \\
& FAB-14 & $2.03 \pm 0.47$ & 4.64 & $2.37-7.26$ & 10.1 & 105 \\
& FAB-15 & $1.65 \pm 0.38$ & 2.39 & $1.33-3.59$ & 5.2 & 105 \\
& MBO-14 & $1.32 \pm 0.22$ & 2.57 & $1.42-3.95$ & 5.6 & 175 \\
& MBO-15 & $3.53 \pm 0.74$ & 5.18 & $3.93-6.26$ & 11.3 & 210 \\
& SAN & $1.23 \pm 0.34$ & 0.35 & $0.03-0.81$ & 0.8 & 210 \\
& DIA & $2.27 \pm 0.37$ & 1.58 & $1.10-2.04$ & 3.4 & 210 \\
KMN & $3.69 \pm 0.70$ & 2.59 & $1.87-3.20$ & 5.6 & 190 \\
LAR & $1.63 \pm 0.32$ & 1.75 & $0.90-2.57$ & 3.8 & 210 \\
NDI & $0.61 \pm 0.29$ & 0.98 & $0.00-4.49$ & 2.1 & 70
\end{tabular}




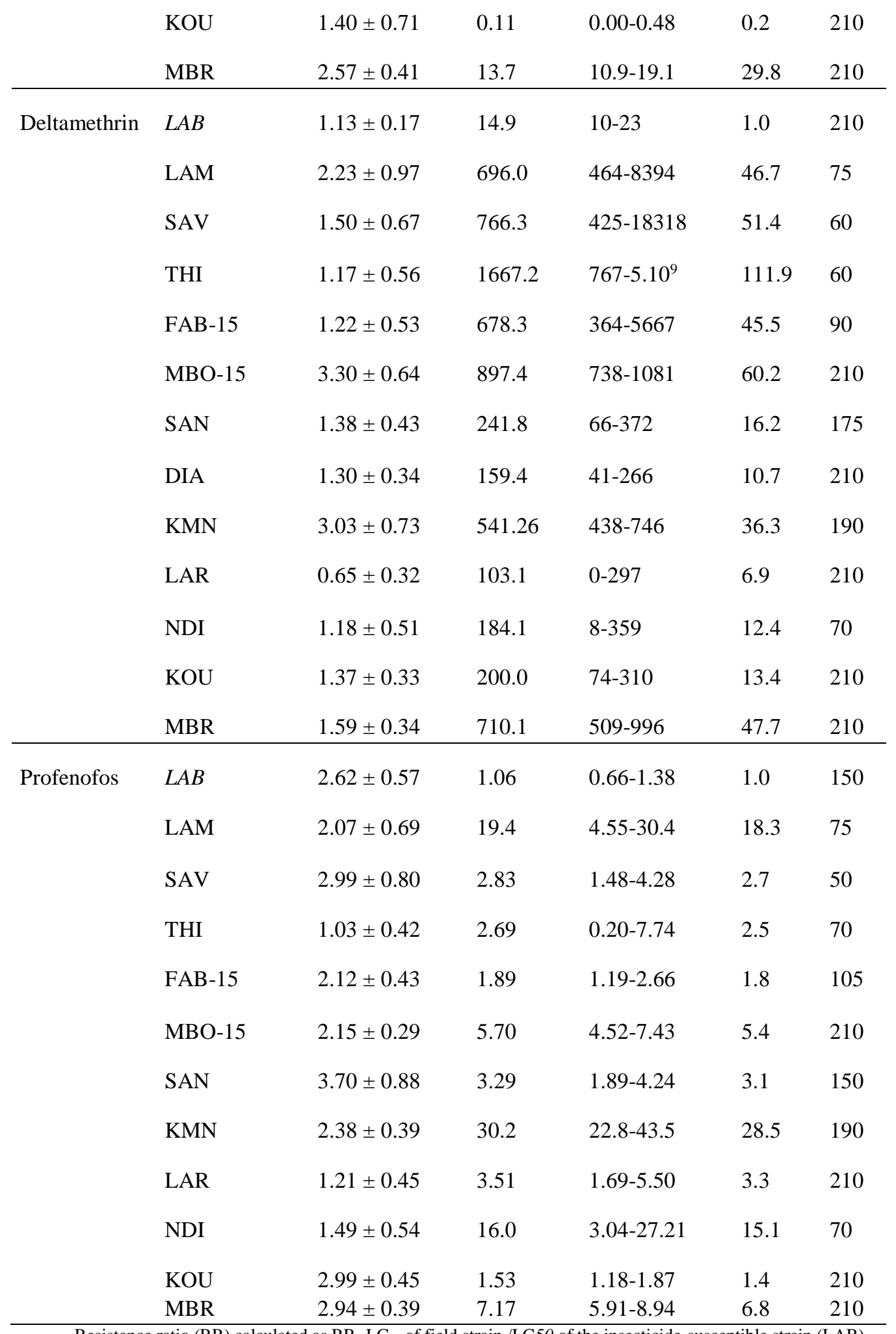




\section{DISCUSSION}

Tomato production is of strategic importance and has significantly increased to meet urban demand for fresh market or processing tomato (FAO, 2015). It has an annual variation of 10 and $-1.1 \%$ (respectively for industrial and cherry tomatoes) (ANSD, 2019). The fruitworm, H. armigera, is the most destructive pest of field-grown tomato in Senegal (Diatte et al., 2018). In addition, the introduction in 2012 of the tomato leafminer, Tuta absoluta, has increased farmer's reliance upon insecticides (Brévault et al., 2014). The monitoring of the susceptibility to commonly used insecticides (abamectin, deltamethrin, and profenofos), using a standard leaf-dip bioassay, showed that $H$. armigera populations collected from tomato fields, have evolved high levels of resistance to pyrethroid insecticides (11/12 populations with $\mathrm{RR}>10,7 / 12$ populations with $R R>30$ ). Moreira et al. (2002) already suspected resistance to pyrethroids in a $H$. armigera population from tomato in Northern Senegal (Saint-Louis), when they identified two mutations located in the sodium voltage dependent channel gene, the main target of pyrethroids. The level of resistance increased significantly from the South (1/4 populations with $R R>30$ ) to the North (3/3 populations with $R R>30$ ) of Niayes. In the North of Niayes, field-grown tomato is mostly dedicated to processing industry, occupies large areas (4500 ha), and relies on intensive use of pesticides, compared to small-size tomato plots conducted by smallholders (3-4 ha) in The South and Center of Niayes. In addition, large surfaces of alternative host crops for $H$. armigera such as sweet corn planted by agro-industrial companies, are also heavily sprayed with pyrethroids. The only population collected from cotton in the Eastern part of Senegal showed moderate resistance level $(R R=13)$ compared to populations from tomato, probably because programs of insecticide resistance management temporally excluding pyrethroids have been implemented on the whole cultivated cotton area (Martin et al., 2005; Badiane et al., 2015).

Low to moderate levels of resistance to OPs $(8 / 11$ populations with $R R<10)$ or newer chemistries such as abamectin (11/15 populations with $R R<10$ ) were observed. Special attention should be paid to some cases of resistance to abamectin as this insecticide has been increasingly used these last years for the control of vegetable pest in Senegal. In addition, cross-resistance with pyrethroidresistant populations was detected. Elevated metabolic detoxification already selected in pyrethroid-resistant populations might be responsible for this cross-resistance because abamectin does not share target sites with other classes of insecticides. Conventional insecticides such as synthetic pyrethroids generally act on the sodium-potassium channel, while organophosphates act as acetylcholinesterase inhibitors. Abamectin belongs to the avermectins group and acts as chloride channel activator. Different levels of cross-resistance to various insecticides within and outside the pyrethroid group such as abamectin has been reported in the CRR strain of Musca domestica (Zhang et al., 2007) and according to Liang et al. (2003) there is little cross-resistance between abamectin and four pyrethroid insecticides (deltamethrin, betacypermethrin, fenvalerate and bifenthrin) in a strain of the diamondback moth, Plutella xylostella $(\mathrm{L})$. This suggests abamectin is not necessarily an effective tool for the management of pyrethroid $H$. armigera resistance in Senegal. The use of more selective novel-chemistry insecticides with different modes of action such as insect growth regulators (lufenuron, methoxyfenozide, etc.), diamides (chlorantraniliprole, flubendiamide), oxadiazines (indoxacarb), or spinosyns (spinosad, spinetoram), associated to threshold-based sprayings to better target sprays (Silvie et al., 2013), could partly (rotation) or totally (exclusion) replace insecticides at risk (herein pyrethroids).

Better knowledge of the scope and magnitude of resistance of $H$. armigera provides essential information to help farmers to adapt their pest management practices. Priority actions should focus on the rational and concerted use of pesticides at the regional scale, considering major host crops of $H$. armigera, in the framework of an area-wide insect resistance management plan. This entails research efforts for a better understanding of 
genetic and demographic flows of $H$. armigera populations among agricultural production areas and crops in Senegal, and more broadly in West Africa. This also entails cooperation between major stakeholders including farmers, agrochemical industry, research, and extension services (Martin et al., 2005). Capacity building of stakeholders to use biorational insecticides, low doses, targeted applications (temporal or spatial), should be also encouraged to enhancing biological control by indigenous natural enemies (Barzman et al., 2015). This approach could effectively support the transition of farming systems to ecologically-based production reducing the reliance on insecticides.

\section{Conclusion}

Research in this study has focused on the use of synthetic chemicals in various agroecosystems as strategies to control $H$. armigera. The results revealed high levels of pyrethroid resistance in several populations of H. armigera in the Niayes area. A pattern of increasing resistance to deltamethrin was observed from south to north. The study also showed that the susceptibility of larvae to abamectin and profenofos is high in general. However, an evolution of resistance to these two products within some populations has been noted. Low yields and high production costs are among the consequences of this resistance. An agroecological approach, including good cultural practices and biological control methods is therefore necessary. Further investigation will be needed to evaluate effects of biological pesticides for developing more appropriate, cost-effective and sustainable integrated protection strategies.

\section{COMPETING INTERESTS}

No potential competing interest was reported by the authors.

\section{AUTHORS' CONTRIBUTIONS}

SOS is the principal investigator, ET and MD defined the protocols and participated all the activities. SS, AOD and BL participated in writing the manuscript. $\mathrm{KD}$ is the initiator of the project.

\section{ACKNOWLEDGEMENTS}

We express our sincere gratitude to L2PIA (Laboratoire Production et Protection Intégrées en Agroécosystèmes Horticoles) for financial support.

\section{REFERENCES}

Achaleke J, Martin T, Ghogomu RT, Vaissayre M, Brévault T. 2009. Esterase-mediated resistance to pyrethroids in field populations of Helicoverpa armigera (Lepidoptera: Noctuidae) from Central Africa. Pest Manag. Sci., 65(10): 114754. DOI: https://doi.org/10.1002/ps.1807

Ahmad M. 2004. Potentiation/antagonism of deltamethrin and cypermethrins with organophosphate insecticides in the cotton bollworm, Helicoverpa armigera (Lepidoptera: Noctuidae). Pestic. Biochem. Physiol., 80: 31-42. DOI: https://doi.org/10.1016/j.pestbp.2004.06. 002

Ahmad M, Arif MI, \& Ahmad M. 2007. Occurrence of insecticide resistance in field populations of Spodoptera litura (Lepidoptera: Noctuidae) in Pakistan. Crop Prot., 26: 809-817. DOI: https://doi.org/10.1016/j.cropro.2006.07. 006

Alvi AHK, Sayyed AH, Naeem M, Ali M. 2012. Field Evolved Resistance in Helicoverpa armigera (Lepidoptera: Noctuidae) to Bacillus thuringiensis Toxin Cry1Ac in Pakistan. PLoS ONE., 7(10): e47309. DOI: https://doi.org/10.1371/journal.pone.004 7309

ANSD (Agence Nationale de la Statistique et de la Démographie), 2019. Bulletin mensuel des statistiques économiques. Première partie : Secteur primaire ; Titre I.4 : Horticulture, 112 p.

Badiane D, Gueye MT, Coly EV, Faye O. 2015. Gestion intégrée des principaux ravageurs du cotonnier au Sénégal et en Afrique occidentale. Int. J. Biol. Chem. Sci., 9: 2654-2667. DOI : http://dx.doi.org/10.4314/ijbcs.v9i5.36

Barzman M, Barberi P, Birch AN, Boonekamp P, Dachbrodt-Saaydeh S, Graf B, Hommel B, Jensen JE, Kiss J, Kudsk P, Lamichhane JR, Messéan A, Moonen 
AC, Ratnadass A, Ricci P, Sarah JL, Sattin M. 2015. Eight principles of integrated pest management. Agron. Sustain. Dev., 35: 1199-1215. DOI: https://doi.org/10.1007/s13593-0150327-9

Brévault T, Sylla S, Diatte M, Bernadas G, Diarra K. 2014. Tuta absoluta Meyrick (Lepidoptera: Gelechiidae): a new threat to tomato production in Sub-Saharan Africa. Afr. Entomol., 22 : 441-444. DOI: https://doi.org/10.4001/003.022.0202

CABI, 2016. Invasive species compendium. http://www.cabi.org/isc/datasheet/26757.

Che W, Shi T, Wu Y, Yang Y. 2013. Insecticide resistance status of field populations of Spodoptera exigua (Lepidoptera: Noctuidae) from China. $J$. Econ. Entomol., 106: 1855-1862. DOI: https://doi.org/10.1603/EC13128

Cunningham JP, Zalucki MP. 2014. Understanding Heliothine (Lepidoptera: Heliothinae) Pests: What is a Host Plant? J. Econ. Entomol., 107(3): 881-896. DOI: https://doi.org/10.1603/EC14036

Czepak C, Albernaz KC, Vivan LM, Guimarães HO, Carvalhais T. 2013. First reported occurrence of Helicoverpa armigera (Hubner) (Lepidoptera: Noctuidae) in Brazil. Pesqui. Agropecu. Trop., 43: 110-113. DOI: https://doi.org/10.1590/S198340632013000100015

Diatte M, Brévault T, Sall-Sy D, Diarra K. 2016. Des pratiques culturales influent sur les attaques de deux ravageurs de la tomate dans les Niayes au Sénégal. Int. $J$. Biol. Chem. Sci., 10 : 681-693. DOI:1 https://doi.org/0.1017/S17427584180000 61

Diatte M, Brévault T, Sylla S, Tendeng E, SallSy D, Diarra K. 2018. Arthropod pest complex and associated damage in fieldgrown tomato in Senegal. Int. J. Trop. Insect Sci., 38(3) : 1 - 11. DOI: https://doi.org/10.1017/S1742758418000 061

Diatte M, Brévault T, Sall-Sy D, Diarra K. 2018. Dynamique des parasitoïdes larvaires de Helicoverpa armigera (Lepidoptera : Noctuidae) dans la zone des Niayes au Sénégal. Int. J. Biol. Chem.
Sci., 12(1): 392- 401. DOI: https://dx.doi.org/10.4314/ijbcs.v12i1.31

Djihinto AC, Katary A, Djaboutou MC, Prudent P, Menozzi P, Atachi P. 2012. Variation in biological parameters of cypermethrin resistant and susceptible strains of Helicoverpa armigera from Benin Republic, West Africa. Int. J. Biol. Chem. Sci., 6(3): 931-940. DOI: http://dx.doi.org/10.4314/ijbcs.v6i3.2

FAO. 2015. FAOSTAT database. Online at: http://faostat3.fao.org/home/E (accessed 25.06.15).

Finney DJ. 1971. Probit Analysis, 3rd edition. Cambridge University Press, London, UK, 333 pp.

Huat J. 2006. Limitative factors of yields in factory-growing tomato fields in Northern Senegal. Cah. Agric., 15(3): 293-300.

IRAC. 2014. IRAC susceptibility test methods series for leaf-eating Lepidoptera (including Heliothis, Helicoverpa) and Coleoptera on cotton, vegetable and field crops, Version 3. (www.iraconline.org/content/uploads/Method_007_ v3 _ june09.pdf) (accessed December 2019).

Liang P, Gao XW, Zeng BZ. 2003. Genetic basis of resistance and studies on crossresistance in a population of diamondback moth, Plutella xylostella (Lepidoptera: Plutellidae). Pest Manag. Sci., 59(11): 1232-1236. DOI: https://doi.org/10.1002/ps.760

Mailafiya DM, Degri MM, Maina YT, Gadzama UN, Galadima IB. 2014. Preliminary studies on insect pest incidence on tomato in Bama, Borno State, Nigeria. Int. Lett. Nat. Sci., 5(10): 45-54.

DOI: https://doi.org/10.18052/www.scipress.c om/ILNS.10.45

Martin T, Ochou GO, Hala-N'Klo F, Vassal JM, Vaissayre M. 2000. Pyrethroid resistance in the cotton bollworm, Helicoverpa armigera (Hübner), in West Africa. Pest Manag. Sci., 56(6): 549-554. DOI: https://doi.org/10.1002/(SICI)15264998(200006)56:6<549::AIDPS160>3.0.CO;2-Y 
Martin T, Ochou GO, Djihinto A, Traoré D, Togola M, Vassal JM, Vaissayre M, Fournier D. 2005. Controlling an insecticide-resistant bollworm in West Africa. Agri. Ecosyst. Environ. 107(4): 409-411.

DOI: https://doi.org/10.1016/j.agee.2004.11.00 6

Mironidis GK, Kapantaidaki D, Bentila M, Morou E, Savopoulou-Soultani M, Vontas J. 2013. Resurgence of the cotton bollworm Helicoverpa armigera in northern Greece associated with insecticide resistance. Insect Sci., 20(4): 505-512.

DOI:

https://doi.org/10.1111/j.1744-

7917.2012.01528.x

Moreira C, Schiffers B, Haubruge E. 2002. Caractérisation de la résistance au Sénégal d'Helicoverpa armigera Hübner (Lepidoptera, Noctuidae) par bioessai et méthodes moléculaires. Parasitica., 58(2-3-4): $\quad 89-98 . \quad$ DOI: http://hdl.handle.net/2268/112902

Ndiaye, O., Diallo, A., Matty, F., Thiaw, A., Fall, R.D., Guisse, A., 2012. Caractérisation des sols de la zone des Niayes de Pikine et de Saint Louis (Sénégal). Int. J. Biol. Chem. Sci., 6(1): 519-528.

DOI : http://dx.doi.org/10.4314/ijbcs.v6i1.46

Nibouche S, Guerard N, Martin P, Vaissayre M. 2007. Modelling the role of refuges for sustainable management of dual-gene Bt cotton in West African smallholder farming systems. Crop Prot., 26(6): 828 836.

DOI: https://doi.org/10.1016/j.cropro.2006.05. 018

Qayyum MA, Wakil W, Arif MJ, Sahi ST, Saeed NA, Russell DA. 2015. Multiple resistances against formulated organophosphates, pyrethroids, and newer-chemistry insecticides in populations of Helicoverpa armigera (Lepidoptera: Noctuidae) from Pakistan. J. Econ. Entomol., 108(1): 286-293. DOI: https://doi.org/10.1093/jee/tou037

Scott JG. 1989. Cross-resistance to the biological insecticide abamectin in pyrethroid resistant house flies. Pestic. Biochem. Physiol., 34(1): 27-31. DOI: https://doi.org/10.1016/00483575(89)90137-5

Sharma HC. 2005. Heliothis/Helicoverpa Management: Emerging Trends and Strategies for Future Research, chapter 24, Publisher: Oxford \& IBH Publishing Co. Pvt. Ltd: New Delhi; 453 - 463.

Silvie PJ, Renou A, Vodounnon S, Bonni G, Adegnika MO, Héma O, Prudent $P$, Sorèze $\mathrm{J}$, Ochou G, Togola $\mathrm{M}$, Badiane $\mathrm{D}$, Ndour A, Akantetou PK, Ayeva B, Brévault T. 2013. Threshold-based interventions for cotton pest control in West Africa: What's up 10 years later? Crop Prot., 43 : 157-165. DOI: https://doi.org/10.1016/j.cropro.2012.09. 006

Tendeng E, Labou B, Djiba S, Diarra K. 2017. Actualisation de l'entomofaune des cultures maraîchères en Basse Casamance (Sénégal). Int. J. Biol. Chem. Sci., 11(3) : 1021-1028.

DOI

https://dx.doi.org/10.4314/ijbcs.v11i3.7

Torres-Vila LM, Rodriguez-Molina MC, Lacasa-Plasencia A. 2003. Impact of Helicoverpa armigera larval density and crop phenology on yield and quality losses in processing tomato: developing fruit count-based damage thresholds for IPM decision-making. Crop Prot., 22: 521-532.

DOI: https://doi.org/10.1016/S02612194(02)00205-3

Umeh VC, Kuku FO, Nwanguma EI, Adebayo OS, Manga AA. 2002. A survey of the insect pests and farmers' practices in the cropping of tomato in Nigeria. Tropicultura 20, 181-186.

Zhang L, Gao X, Liang P. 2007. Betacypermethrin resistance associated with high carboxylesterase activities in a strain of house fly, Musca domestica (Diptera: Muscidae). Pestic. Biochem. Physiol., 89(1): 65-72. DOI: https://doi.org/10.1016/j.pestbp.2007.03. 001. 